\title{
Life cycle assessment of waste incineration in Denmark and Italy using two LCA models
}

Turconi, Roberto; Butera, Stefania; Boldrin, Alessio; Grosso, Mario; Rigamonti, Lucia; Astrup, Thomas

Published in:

Waste Management and Research

Link to article, DOI:

10.1177/0734242X11417489

Publication date:

2011

Document Version

Peer reviewed version

Link back to DTU Orbit

Citation (APA):

Turconi, R., Butera, S., Boldrin, A., Grosso, M., Rigamonti, L., \& Astrup, T. (2011). Life cycle assessment of waste incineration in Denmark and Italy using two LCA models. Waste Management and Research, 29(10 suppl.), 78-90. https://doi.org/10.1177/0734242X11417489

\section{General rights}

Copyright and moral rights for the publications made accessible in the public portal are retained by the authors and/or other copyright owners and it is a condition of accessing publications that users recognise and abide by the legal requirements associated with these rights.

- Users may download and print one copy of any publication from the public portal for the purpose of private study or research.

- You may not further distribute the material or use it for any profit-making activity or commercial gain

- You may freely distribute the URL identifying the publication in the public portal 


\title{
Life cycle assessment of waste incineration in Denmark and Italy using two LCA models
}

\author{
Turconi, R. ${ }^{1,2}$, Butera, S. ${ }^{1,2}$, Boldrin, A. ${ }^{1}$, Grosso, M. ${ }^{2}$, Rigamonti, L. ${ }^{2}$, Astrup, T. ${ }^{1}$ \\ ${ }^{1}$ Department of Environmental Engineering \\ Technical University of Denmark \\ Kgs. Lyngby, Denmark \\ ${ }^{2}$ DIIAR - Environmental Section \\ Politecnico di Milano \\ Piazza Leonardo da Vinci 32 \\ 20133 Milano, Italy
}

"NOTE: this is the author's version of a work that was accepted for publication in Waste Management journal. Changes resulting from the publishing process, such as peer review, editing, corrections, structural formatting, and other quality control mechanisms may not be reflected in this document. Minor changes may have been made to this manuscript since it was accepted for publication.
A definitive version is published in Waste Management, vol 29, pp 78-90, doi: 10.1177/0734242x11417489" 


\begin{abstract}
In Europe, about $20 \%$ of municipal solid waste is incinerated. Large differences can be found between Northern and Southern Europe regarding energy recovery efficiencies, flue gas cleaning technologies and residue management. Life cycle assessment (LCA) of waste incineration often provides contradictory results if these local conditions are not properly accounted for. The importance of regional differences and site-specific data, and choice of LCA model itself, was evaluated by assessment of two waste incinerators representing Northern and Southern Europe (Denmark and Italy) based on two different LCA models (SimaPro and EASEWASTE). The results showed that assumptions and modelling approaches regarding energy recovery/substitution and direct air emissions were most critical. Differences in model design and model databases mainly had consequences for the toxicity related impact categories. The overall environmental performance of the Danish system was better than the Italian, mainly because of higher heat recovery at the Danish plant. Flue gas cleaning at the Italian plant was however preferable to the Danish, indicating that efficient flue gas cleaning may provide significant benefits. Differences in waste composition between the two countries mainly affected Global Warming and Human Toxicity via Water. Overall, SimaPro and EASEWASTE provided consistent ranking of the individual scenarios. However, important differences in results from the two models were related to differences in the databases and modelling approaches, in particular the possibility for modelling of waste-specific emissions affected the toxicity related impact categories. The results clearly showed that the use of sitespecific data was essential for the results.
\end{abstract}

Keywords: waste incineration, life cycle assessment, energy recovery, air emissions 


\section{Introduction}

In Europe, approximately 48 million $\mathrm{Mg}$ of municipal solid waste are incinerated annually, corresponding to about $20 \%$ of the municipal waste generated (Eurostat 2009). Today, waste incineration represents the most mature and robust technology for energy recovery of municipal solid waste, and can be considered an essential part of a sustainable waste management system.

Within the last decade, life cycle assessment (LCA) has been extensively used to evaluate waste management systems, including waste incineration. Several case studies have been carried out, comparing incineration with other technologies such as anaerobic digestion, co-combustion, landfilling and various levels of recycling, in order to optimise waste management strategies (e.g. Finnveden \& Ekvall 1998, Mendes et al. 2004, Schmidt et al. 2007, Liamsanguan \& Gheewala 2008, Rigamonti et al. 2009, Fruergaard \& Astrup 2011). In these studies, downstream use of recovered energy often plays an important role together with assumptions regarding the substitution of other fuels for energy production (e.g. Astrup et al. 2009, Fruergaard et al. 2009, Fruergaard \& Astrup 2010).

Reimann (2009) performed a survey of 231 European waste incinerators: the study found large differences between Northern Europe (e.g. Denmark, Sweden, Germany, Holland) and Southern Europe (e.g. Italy, Spain, parts of France) rendering the environmental footprint of waste incineration very different across Europe. In addition to the differences associated with the local regulatory framework and the specific climatic conditions, other differences related to the technology and mode of operation may to a higher degree be the result of local practices and traditions. Often life cycle assessments focusing on incineration do not address these local differences, although the assessment may include waste treatment in different countries and regions (Consonni et al. 2005, Emery et al. 2007, Schmidt et al. 2007).

A number of different LCA models have been used for evaluating waste incineration, e.g. EASEWASTE (Riber et al. 2008), SimaPro (Pré Consultants 2008), Gabi (PE International 2010). To be considered comprehensive and robust, the results of an LCA study should not be model dependent. However, studies have demonstrated that the model itself can significantly affect the conclusions of LCA studies, and lead to discrepancies in impacts of up to $1400 \%$ and potentially to contradictory results (Winkler \& Bilitewski 2007). Without sufficient understanding of the importance of local conditions and implementation of these in LCA models as well as the model choice itself, it may not be possible to completely trust the results of LCAs concerning the sustainability of waste incineration in a specific context.

The objective of this paper is to provide a quantitative assessment of the importance of local conditions and model choice for the environmental profile of waste incineration in two significantly different contexts: Northern and Southern Europe. This is done by: 1) modelling the environmental performance of an Italian and a Danish municipal solid waste incinerator in a consequential LCA perspective, using two LCA modelling tools (SimaPro and EASEWASTE), 2) evaluating the LCA results with respect to important differences in waste composition, plant operation, residues management and energy substitution and 3) evaluating the robustness of the LCA conclusions by identifying the influence of modelling and parameter choices. 


\section{Material and methods}

\subsection{Goal and scope of the LCA}

The goal of the LCA was to define the environmental footprints of two incineration facilities located in Italy and Denmark. The results refer to incineration of $1 \mathrm{Mg}$ of wet waste $\left(\mathrm{Mg} \mathrm{ww}_{\mathrm{w}}\right)$ as received at the gate of the plant. The system boundaries were extended "from gate to grave", i.e. from the entrance to the incineration plant until the final disposal of all solid residues. Recovery of energy and materials were included in the assessment, while waste collection and capital goods (commissioning, maintenance and decommissioning) were disregarded. The LCA was performed following the common practice described by Wenzel et al. (1997) and Finnveden et al. (2009) and a time horizon of 100 years for the emissions was considered. The LCA was conducted according to a consequential approach, meaning that system expansion was performed to include the consequences (e.g. in the energy sector) caused by a change in the modelled system. The analysed change was the additional incineration of $1 \mathrm{Mg}$ of waste. System expansion was modelled using marginal life cycle inventory ( $\mathrm{LCl}$ ) data when available, as widely recommended in literature (e.g. Finnveden et al. 2009).

The impact assessment was carried out based on the EDIP97 method (Wenzel et al. 1997), employing the latest characterization and normalization factors (Stranddorf et al. 2005). The results were presented as normalized potential impacts - expressed as person equivalents (PE) calculated on an EU-15 basis - and grouped into eight impact categories (Wenzel et al. 1997): four non-toxic categories, i.e. Global Warming, Acidification, Nutrient Enrichment and Photochemical Ozone Formation, and four toxic categories, i.e. Eco-Toxicity to Water, Human Toxicity via Air, Human Toxicity via Water, and Human Toxicity via Soil. Characterization factors for Global Warming were further updated with GWPS 100 from IPCC (2007). Results for Ozone Depletion and Ecotoxicity to soil were calculated but not presented, as their overall contributions were found to be negligible.

\subsection{LCA modelling tools}

The LCA modelling tools EASEWASTE version 2008 (Kirkeby et al. 2006) and SimaPro version 7.1 (Pré Consultants 2008) were used and compared in the assessment. The two models included a range of features which could potentially influence the results of the assessment. The EASEWASTE model was specifically developed for waste management systems and technologies, while SimaPro is a more generic product-oriented tool, which can cover a wider technological area. Being a specific waste-LCA model, EASEWASTE makes use of mass-balances to track waste quantities and material flow compositions throughout the individual treatment steps. Furthermore, EASEWASTE considers two types of emissions from waste treatments: process-specific and input-specific emissions. Process-specific emissions are quantified as the amount of a substance (e.g. in $\mathrm{kg}$ ) per Mg of waste treated. The magnitude of process-specific emissions typically depends on the operative conditions of the plant or the pollution control system installed (e.g. $\mathrm{CO}$, dioxins and $\mathrm{HCl}$ ). Input-specific (also called waste-specific) emissions are quantified by means of transfer coefficients, which define the fraction of the input mass (i.e. the mass of a substance contained in the waste) transferred to the individual outputs, e.g. flue gas, air pollution control (APC) residues, bottom ashes, leachate from landfills etc. Transfer coefficients typically apply to heavy metals (Damgaard et al. 2010). SimaPro

only considers process-specific emissions and the composition of the input waste has no influence on the emissions. 


\section{3. $\quad \mathrm{LCl}$ databases}

SimaPro was based on a commercial inventory, ecoinvent, which is a validated database containing more than 2500 processes (Frischknecht \& Rebitzer 2005). On the other hand, the EASEWASTE database was established using data from different sources, including: existing databases such as EDIP (LCA-center 2008), inventories developed for previous LCA studies (Riber et al. 2008) and datasets compiled by the developers.

Several studies (e.g. Finnveden et al. 2005, Fruergaard et al. 2009, Fruergaard \& Astrup 2011) have highlighted the importance of energy substitution modelling on the final results of the assessment. Thus, to provide a consistent and up-to-date assessment and to perform a fair comparison between the two incinerators and the models, datasets for energy and heat production in both countries and recycling of metals were updated with the latest values available: data concerning electricity production were based on ecoinvent, while data regarding heat production were based on data for local facilities (Regione Lombardia 2004, DONG Energy 2008). In case of cogeneration of heat and electricity, emission data were allocated according to exergy following the principles described in Fruergaard et al. (2009) and Fruergaard \& Astrup (2011). Data for the recycling of metals was based on the Best Available Techniques (BAT) references for aluminium (IPPC, 2001) and for steel (IPCC, 2009).

\subsection{Waste incinerators: Milan and Aarhus}

The two incineration plants studied were Milan (45 $\left.30^{\prime} 17^{\prime \prime} \mathrm{N}, 9^{\circ} 4^{\prime} 15^{\prime \prime} \mathrm{E}\right)$ located in the north-western part of Milano (Italy), and Aarhus (56 $13^{\prime} 41^{\prime \prime} \mathrm{N}, 10^{\circ} 9^{\prime} 29^{\prime \prime} \mathrm{E}$ ) located in Eastern Jutland, Denmark. Both facilities operated three lines equipped with moving grate furnaces. The flue gas cleaning system in Milan was based on three identical lines equipped with a dry scrubbing system while Aarhus relied on two lines equipped with semi-dry systems and one line with a wet system. Differences in incinerator technology, flue gas cleaning systems, energy recovery efficiencies and the fate of solid residues can be seen in Table 1 . Figure 1 and 2 present the technical layouts of the two facilities.

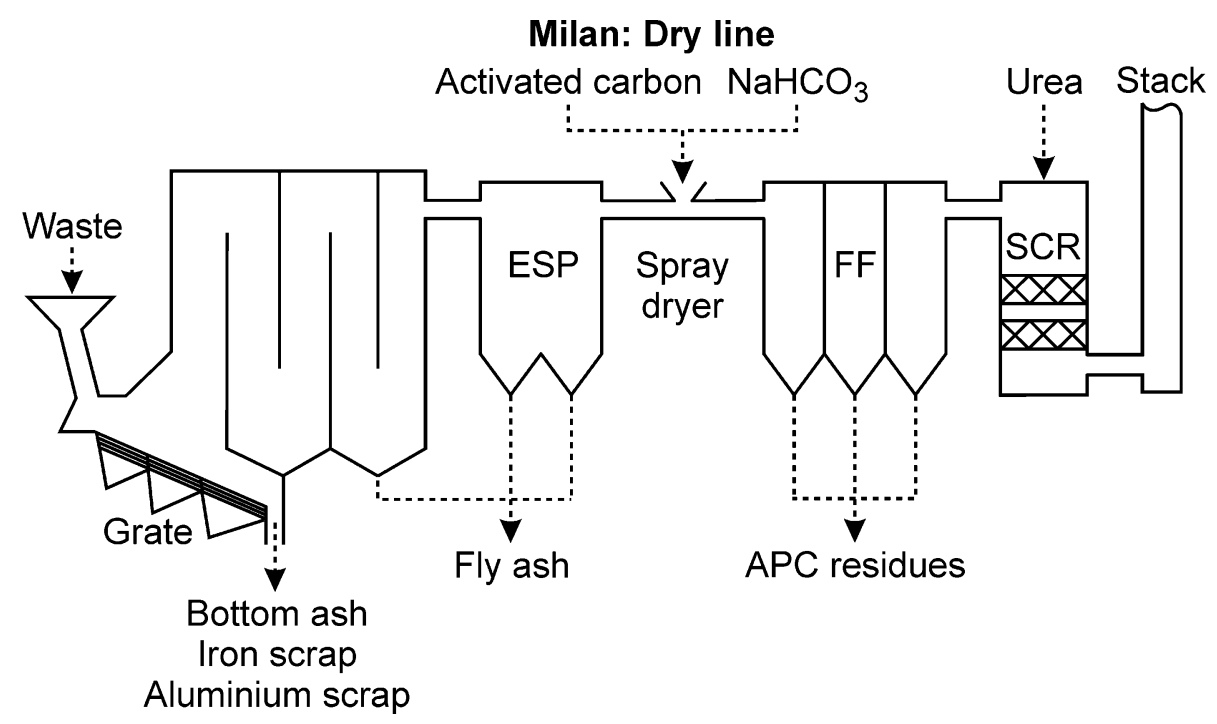

Figure 1. Technical layout of the Milan incinerator. FF = Fabric Filters, ESP = Electrostatic Precipitator, SCR $=$ Selective Catalytic Reduction. 
Table 1: Life Cycle Inventory (LCI) data for the two incinerators: Milan (IT) and Aarhus (DK). Data were from Amsa (2008) for Milan, and from AffaldVarme Aarhus (2008) and Riber et al. (2008) for Aarhus.

\begin{tabular}{|c|c|c|c|}
\hline & Unit & Milan & Aarhus \\
\hline \multicolumn{4}{|l|}{ Technical configuration } \\
\hline Scrubbing & & 3 dry lines & 1 wet +2 semidry lines \\
\hline Pre-dusting & & All lines & On semidry lines only \\
\hline Micropollutants removal & & Injection of activated carbon & Injection of activated carbon \\
\hline Particle removal & & Fabric filter & Fabric filter \\
\hline Flue gas condensation & & No & Yes \\
\hline Acid gases removal & & $\mathrm{NaHCO}_{3}$ injection & $\begin{array}{c}\mathrm{CaCO}_{3} \text { in all lines (together with } \\
\mathrm{NaOH} \text { in the wet line) }\end{array}$ \\
\hline deNOx - technology & & Catalytic (urea) & Non-Catalytic (ammonia) \\
\hline \multicolumn{4}{|l|}{ Input Waste } \\
\hline Amount & $\operatorname{Mg}_{w w} y^{-1}$ & 450,000 & 230,000 \\
\hline Lower Heating Value & $M J t_{w w}^{-1}$ & 10,900 & 9,300 \\
\hline \multicolumn{4}{|l|}{ Energy recovery } \\
\hline$\eta_{\text {HEAT }}$ & & $5.5 \%$ & $74.0 \%$ \\
\hline$\eta_{\text {ELECTRICITY, NET }}$ & & $24.2 \%$ & $20.7 \%$ \\
\hline \multicolumn{4}{|l|}{ Material use } \\
\hline Activated carbon & $\mathrm{kg} \mathrm{Mg} \mathrm{ww}^{-1}$ & 0.83 & 0.63 \\
\hline Ammonia $\left(\mathrm{NH}_{3}\right)$ & $\mathrm{kg} \mathrm{Mg}_{w w^{-1}}$ & - & 1.5 \\
\hline Calcium Carbonate $\left(\mathrm{CaCO}_{3}\right)$ & $\mathrm{kg} \mathrm{Mg}_{w w^{-1}}$ & - & 4 \\
\hline Hydrocloric Acid (HCl) & $\mathrm{kg} \mathrm{Mg}_{w w^{-1}}$ & 0.23 & - \\
\hline Calcium Hydroxide $\left(\mathrm{Ca}(\mathrm{OH})_{2}\right)$ & $\mathrm{kg} \mathrm{Mg}_{w w}{ }^{-1}$ & - & 3 \\
\hline Sodium Hydroxide $(\mathrm{NaOH})$ & $\mathrm{kg} \mathrm{Mg}_{w w}{ }^{-1}$ & 0.23 & 1.1 \\
\hline Fuel Oil & $\mathrm{kg} \mathrm{Mg}_{w w}{ }^{-1}$ & 8.7 & 0.4 \\
\hline Sodium Bicarbonate $\left(\mathrm{NaHCO}_{3}\right)$ & $\mathrm{kg} \mathrm{Mg}_{w w^{-1}}$ & 16.8 & - \\
\hline Sodium Hypochlorite ( $\mathrm{NaClO})$ & $\mathrm{kg} \mathrm{Mg}_{w w^{-1}}$ & 0.19 & - \\
\hline Urea $\left(\mathrm{CO}\left(\mathrm{NH}_{2}\right)_{2}\right)$ & $\mathrm{kg} \mathrm{Mg}_{w w^{-1}}$ & 0.86 & - \\
\hline \multicolumn{4}{|l|}{ Air emissions } \\
\hline $\mathrm{CO}_{2}$ fossil & $\mathrm{kg} \mathrm{Mg}_{w w}{ }^{-1}$ & 452 & 280 \\
\hline $\mathrm{NO}_{\mathrm{x}}$ & $\mathrm{g} \mathrm{Mg}_{w w}{ }^{-1}$ & 265 & 1060 \\
\hline $\mathrm{SO}_{x}$ & $\mathrm{~g} \mathrm{Mg}_{\mathrm{ww}}{ }^{-1}$ & 2.7 & 4.76 \\
\hline $\mathrm{NH}_{3}$ & $\mathrm{~g} \mathrm{Mg}_{w w^{-1}}$ & 4.8 & $4.8^{*}$ \\
\hline $\mathrm{HCl}$ & $\mathrm{g} \mathrm{Mg}_{w w^{-1}}$ & 12.7 & 21.9 \\
\hline Dust & $\mathrm{g} \mathrm{Mg}_{w w^{-1}}$ & 0.60 & 3.04 \\
\hline $\mathrm{Hg}$ & $\mathrm{g} \mathrm{Mg}_{w w}{ }^{-1}$ & 0.013 & 0.020 \\
\hline $\mathrm{Pb}$ & $\mathrm{mg} \mathrm{Mg}_{w w^{-1}}$ & 4.0 & 19.7 \\
\hline $\mathrm{Cd}$ & $\mathrm{mg} \mathrm{Mgww}^{-1}$ & 7.4 & 18.1 \\
\hline As & $m g g_{w w}{ }^{-1}$ & 3.3 & 10.6 \\
\hline Dioxin & ng TE $\mathrm{Mg}_{w w^{-1}}$ & 12.1 & 108 \\
\hline Solid outputs & & Fate & Fate \\
\hline Fly ashes & $\mathrm{kg} \mathrm{Mg}_{w w}{ }^{-1}$ & 21.7 Backfilling of mines & 13.3 Backfilling of mines \\
\hline $\mathrm{APC}$ residues & $\mathrm{kg} \mathrm{Mg}_{w w}{ }^{-1}$ & 12.6 Recycled & 10.0 Backfilling of mines \\
\hline Bottom ashes & $\mathrm{kg} \mathrm{Mg}_{w w^{-1}}$ & 118 Recycled** & 104 Recycled \\
\hline Iron scraps & $\mathrm{kg} \mathrm{Mg}_{w w}{ }^{-1}$ & 9.0 Recycled & 13.1 Recycled \\
\hline Aluminium scraps & $\mathrm{kg} \mathrm{Mg}_{w w^{-1}}$ & 1.3 Recycled & 0.5 Recycled \\
\hline
\end{tabular}



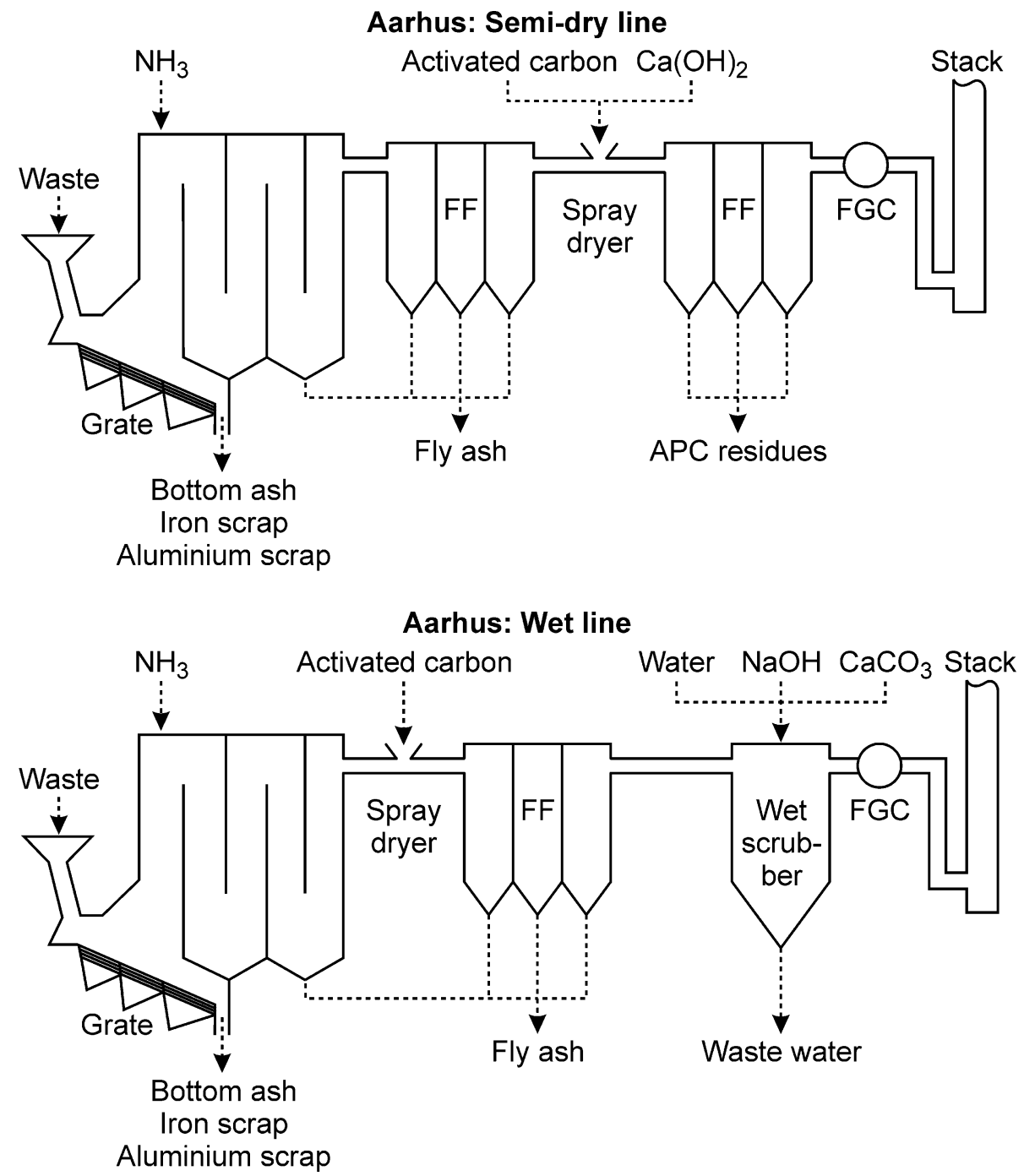

Figure 2. Technical layout of the Aarhus incinerator: semi-dry system (top), wet system (bottom). FF = Fabric Filters, ESP = Electrostatic Precipitator, SCR = Selective Catalytic Reduction, FGC = Flue Gas Condensation, APC = Air Pollution Control

Considerable differences in energy recovery existed for the two plants. The efficiency of electricity generation was larger in Milan (24\%) than in Aarhus (21\%). However, heat recovery was significantly larger in Aarhus (74\%) than in Milan (5.5\%).

Metals and fly ash had similar handling in the two incineration plants: metals were sorted from bottom ash and recycled, while fly ashes were utilized for backfilling of mines. APC residues and bottom ashes had different fates in the two countries. APC residues in Aarhus were disposed together with the fly ashes for backfilling of mines. The APC residues in Milan were recycled by means of the NEUTREC ${ }^{\circledR}$ process developed by Solvay, with production of brine (to be reused by Solvay for sodium carbonate production) and a solid residue that was landfilled. All bottom ashes generated in Aarhus were utilized as aggregates in road construction, while in Italy a small fraction (12\% on weight basis) was sorted out and landfilled, before the main part was utilized for road construction.

Differences related to waste composition can be seen in Table 2 where the material fraction composition for the waste received at the two incineration plants is reported. The waste delivered 
to Aarhus had lower contents of plastic and paper and higher amounts of organic waste compared with Milan. The waste input at Aarhus therefore had a lower Lower Heating Value (LHV) and a higher content of biogenic C compared with Milan.

Table 2: Material fraction composition of input waste as received at the two incineration plants. Data were from Amsa (2008) for Milan, and AffaldVarme Aarhus (2008) and Riber et al. (2008) for Aarhus.

\begin{tabular}{lcc}
\hline \multicolumn{1}{c}{$\%$} & Aarhus & Milan \\
\hline Organic & 42.4 & 12.6 \\
Paper & 30.9 & 39.2 \\
Plastic & 9.4 & 27.6 \\
Glass & 6.8 & 3.9 \\
Wood & 4.0 & 5.9 \\
Ferrous metals & 2.1 & 1.6 \\
Non ferrous metals & 1.0 & 0.8 \\
Others & 3.5 & 8.3 \\
\hline & 100 & 100 \\
\hline
\end{tabular}

\subsection{Energy substitution}

Electricity and heat produced at the incinerators were delivered to the electricity grid and district heating network thus substituting energy produced by other sources. In consequential LCA, this substitution is modelled by system expansion where the substituted energy source is the technology most likely to respond to a change in demand (Fruergaard et al. 2009, Fruergaard \& Astrup 2011). While the responding technology for electricity substitution can be identified at a system level, local conditions nearby the individual waste-to-energy (WtE) plants have to be considered when identifying the responding technology for heat production, as pointed out by Fruergaard et al. (2010a). Energy substitution choices related to the two incinerators are outlined in the following.

In Italy, natural gas was the most important energy resource for electricity production (Figure 3). Electricity production has been steadily increasing over the last decade, mainly based on increased natural gas consumption. Simultaneously oil consumption had decreased at a similar rate. Within the same period, coal played a less significant role, contributing to a minor share of the total production. In a growing electricity market, such as the Italian, the responding technology meeting this increased energy demand is also the one which will be affected by increased electricity production from waste. For Italy, this means that increased electricity production from waste will most likely reduce the need for additional electricity production from natural gas. Electricity substitution for Milan was therefore defined as a natural gas power plant with average efficiencies for Italy (i.e. $\eta_{\mathrm{EL}, \mathrm{GROSS}}=37 \%$, from Dones et al. (2007)). Only a small district heating network was established in the area around Milan. The network connected approximately 15,000 households, with the majority of the produced heat at the plant being cooled off. In the Milan area, heating of buildings was carried out predominantly by domestic natural gas boilers which, therefore, has been defined as the substituted technology for heat production in Milan. 

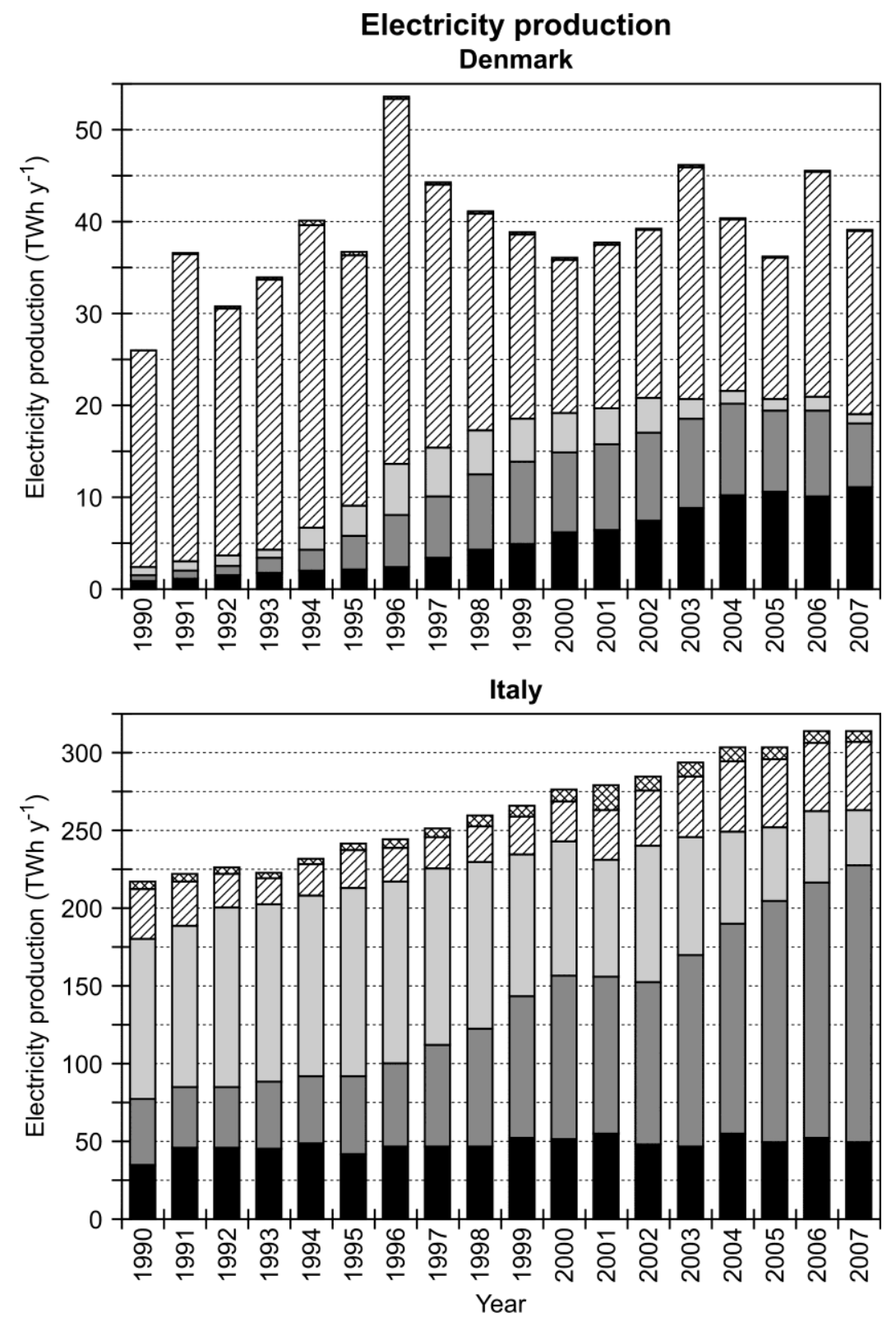

- Renewables $\square$ Gas $\square$ Oil $\square$ Coal $\otimes$ Other

Figure 3. Electricity production by source in Denmark and Italy in the period 1990-2007 (EC 2010).

In Denmark, the electricity production has been relatively stable within the last 10-15 years, although with some variation from year to year depending on the availability of hydro power from Sweden and Norway and electricity import/export. Figure 3 shows that coal has been the energy source principally accommodating these annual fluctuations. On this basis, and because coal power is expected to be gradually phased out over the coming $40-50$ years, coal power plants were most likely to be affected by increased electricity production from waste in Denmark (i.e. waste contributes to this phase out of coal). Coal based electricity has, therefore, been defined as the substituted technology (e.g. Fruergaard et al. 2009, Fruergaard \& Astrup 2011). In the Aarhus area, domestic heating was provided almost exclusively by district heating either from the Aarhus waste incinerator itself or from a large coal fired combined heat and power plant (Studstrup). Heat 
production from Aarhus has thus been assumed to substitute coal based heat at the Studstrup plant (Fruergaard et al. 2010a).

\section{Results and discussion}

Figure 4 shows potential environmental impacts from the two incineration plants as modelled with SimaPro and EASEWASTE. Negative values indicate environmental savings, while positive values represent loads. The impacts were disaggregated into five process contributions: process specific emissions, upstream processes related to material and resource consumption at the incinerator (Astrup et al. 2009), waste specific emissions, and recovered heat and electricity. In both models, non-toxic potential impacts were generally smaller than the toxic categories, except for Global Warming. Furthermore, potential impacts from both incineration systems were dominated by stack emissions, upstream processes and energy recovery, while the management of solid residues and recycling of metals generally did not contribute significantly to the overall results. Note that the environmental profiles of the two incineration plants cannot be directly compared, as the waste inputs were different.
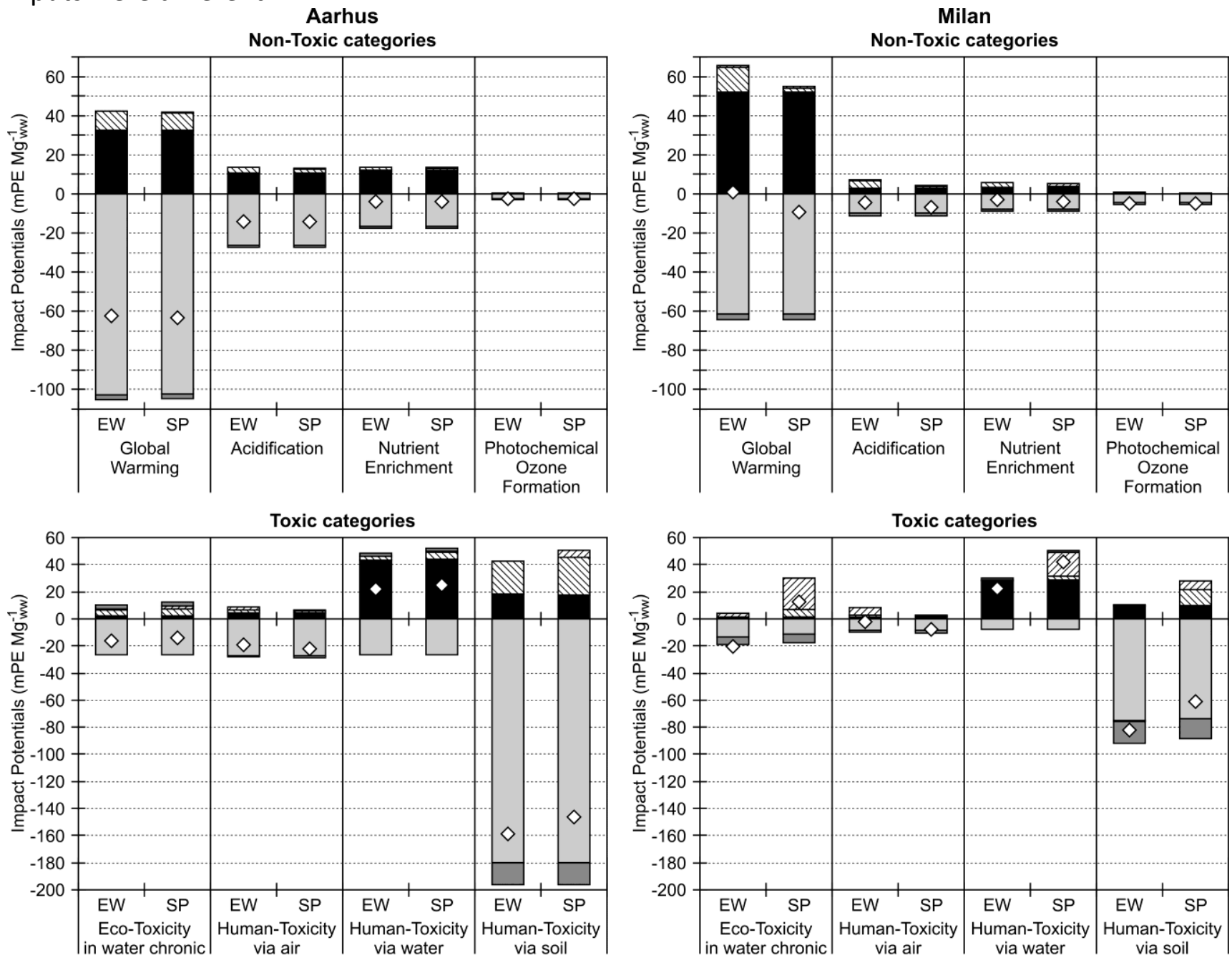

Stack emissions $\mathbb{Q}$ Upstream Processes $\square$ Recovered Energy (Heat + Electricity) $\quad \square$ Solid Residues $\square$ Metal Recycling $\diamond$ Total

Figure 4. Normalized environmental impact potentials for the baseline scenarios (SP = SimaPro, EW = EASEWASTE). 


\subsection{Results for non-toxic impact categories}

Large differences between the two incineration systems were found regarding Global Warming, Acidification and Nutrient Enrichment. These differences were to a large extent due to the savings from avoided heat and electricity production from coal in Denmark and natural gas in Italy. The Italian system was dominated by the savings related to electricity substitution, whereas electricity and heat recovery provided similar contributions to the savings in Aarhus. The different approaches for energy recovery in Italy and Denmark (almost exclusively electricity production in Milan; overall high energy recovery in Aarhus thanks to high heat recovery) thus had significant influences on the results.

Besides energy recovery, direct air emissions from the incinerator stack also had large influence on Global Warming, Acidification and Nutrient Enrichment. For both incinerators, $\mathrm{CO}_{2}$ emissions at the stack were dominating the contributions to Global Warming, while mainly $\mathrm{NO}_{x}$ emissions were responsible for Acidification and Nutrient Enrichment impacts and $\mathrm{CO}$ emissions are greatly responsible for Photochemical Ozone Formation. The differences found for Nutrient Enrichment were due to the different emission factors used for the two plants, which reflected the different $\mathrm{NO}_{x}$ removal technologies adopted: Aarhus plant was equipped with a SNCR system, while in Milan a more efficient SCR system leading to lower $\mathrm{NO}_{x}$ emissions was employed.

The upstream processes contributed to some extent to the non-toxic potential impacts. In particular, in Milan the use of sodium bicarbonate for removal of acidic compounds played a major role. The comparison between the potential impacts from upstream and direct emissions (mainly technology-related) indicated a more optimal configuration in Milan where lower emissions at the stack (direct emissions) could justify the higher consumption of chemicals (resulting in upstream emissions) such as $\mathrm{NaHCO}_{3}$ and $\mathrm{CaCO}_{3}$ (see Table 1). Consequently, the modelling indicated lower potential impacts from "stack + upstream" in the case of Milan than Aarhus for most impact categories. Exceptions to this were Global Warming and Photochemical Ozone Formation. This indicated that future research could focus on identifying the "environmental break-even point" between uses of materials/chemicals associated with upstream emissions and direct emissions from the incinerator.

Similarly to other processes that contributed to non-toxic impacts, metal recycling resulted in small savings in all categories, as recyclable metal represented only about $1 \%$ of the waste input. For the same reason, final disposal of solid residues provided little environmental load overall, because these processes involved only $13-15 \%$ of the initial waste amounts.

\subsection{Results for toxic impact categories}

Both models identify that energy recovery was the main contributor to all impact categories except Human Toxicity via water and Ecotoxicity in water for Milan. In particular, electricity substitution (downstream process) provided slightly larger contributions in Milan, while in Aarhus electricity substitution appeared decisive in all categories with the exception of Human Toxicity via air. Direct emissions at the stack also played an important role for Human Toxicity via water (the only toxicity category with a net environmental burden using both models), for Human Toxicity via soil; the latter were in the same order of magnitude as metal recycling. In both incineration plants the potential impacts on Human Toxicities were related to mercury emissions. In general, flue gas cleaning was more efficient in Milan than in Aarhus resulting in lower emission factors for Milan, especially for 
$\mathrm{NO}_{\mathrm{x}}$ and dust. Lower emission of dust implies lower concentrations of micropollutants, such as heavy metals and dioxins, which are adsorbed on the dust surface.

The toxic potential impacts being a combination of upstream processes and direct emissions showed a similar pattern to the non-toxic categories. The Milan incinerator generated lower environmental loads related to the "stack + upstream" processes for all categories in the SimaPro modelling, indicating once again that a more efficient flue gas cleaning system is environmentally sound despite the higher consumptions of chemicals associated with its operation.

Metal recycling was almost exclusively relevant to the Human Toxicity via soil category. This was because of the small metal quantities contained in the waste input. It should be noted that metal recycling is not necessarily beneficial in all impact categories. In particular, positive impacts arise from steel recycling on Ecotoxicity in water in the Danish scenario, where the share of iron scraps in the waste with respect to the aluminium fraction is higher. Secondary steel production is, in fact, responsible for significant emissions of heavy metals to surface waters.

The management of solid residues (i.e. bottom ash and APC) provided relatively little environmental loads in the toxicity categories. This was a consequence of both the relative small amounts of solid residue and the savings obtained from utilization of bottom ashes (both incineration plants) as well as from recycling of APC residues (only in the Italian scenario). It is worth noting that the potential impacts from bottom ash handling were greater in the Milan scenario for most of the impact categories (Table 3, per Mg of solid residues). The reason for this is twofold: the different waste compositions - resulting in different waste-specific emissions when using EASEWASTE - and the fact that the bottom ashes were subject to pre-treatment before final disposal in the Milan case. The results suggest that, in a life cycle perspective, pre-treatment of bottom ashes before final disposal could represent important environmental loads, as also indicated by Fruergaard et al. (2010b), and that use of site-specific data are important.

Table 3: Relative differences between specific normalized impacts per $\mathrm{Mg}$ of solid residue in Milan and Aarhus. Positive values mean that Milan has larger impacts than Aarhus and vice versa.

\begin{tabular}{|c|c|c|c|c|c|c|}
\hline \multirow[b]{2}{*}{ Impact category } & \multicolumn{3}{|c|}{$\begin{array}{c}\text { EASEWASTE } \\
\% \Delta \text { (Milan - Aarhus)/Milan }\end{array}$} & \multicolumn{3}{|c|}{$\begin{array}{c}\text { SimaPro } \\
\% \Delta \text { (Milan - Aarhus)/Milan }\end{array}$} \\
\hline & $\begin{array}{c}\text { Bottom } \\
\text { ash }\end{array}$ & Fly ash & $\begin{array}{l}\text { APC } \\
\text { residues }\end{array}$ & $\begin{array}{l}\text { Bottom } \\
\text { ash }\end{array}$ & Fly ash & $\begin{array}{l}\mathrm{APC} \\
\text { residues }\end{array}$ \\
\hline Global Warming & 80 & 82 & 130 & 110 & 40 & 230 \\
\hline Acidification & 36 & 86 & 110 & 210 & 27 & 230 \\
\hline Nutrient Enrichment & -0.8 & 72 & 120 & 280 & 25 & 60 \\
\hline Photochemical Ozone Formation & 1300 & 67 & 140 & 250 & 29 & 580 \\
\hline Ecotoxicity in water & 210 & 36 & 43 & -62 & 24 & 95 \\
\hline Human Toxicity via air & 840 & 62 & 430 & 320 & 24 & 220 \\
\hline Human Toxicity via water & -160 & -140 & 220 & 190 & 24 & 97 \\
\hline Human Toxicity via soil & -24 & 55 & 110 & 930 & 25 & 230 \\
\hline
\end{tabular}

\subsection{Model comparison and importance of data in LCA}

Despite the fact that the assessment was performed using two different modelling tools, relatively consistent results were obtained. For all impact categories (except for Ecotoxicity in water and Human Toxicity to water) both models provided the same ranking for the two incineration plants, 
and thus the choice of the model did not affect the overall conclusions. However, the model choice affected the results at a more detailed level as discussed in the following.

The default databases included in the two models were considerably different in two key aspects which could significantly affect the modelling results: data for energy substitution (marginal energy) and metal recycling. Thus, as previously explained, the same datasets for marginal energy were implemented in both databases. Inventory data for external processes (e.g. recycling of metals) were also updated in both databases, corresponding to the most recent IPPC BAT Reference Documents, in order to have identical and up-to-date datasets. The main differences in the databases related to secondary processes, such as the production of sodium bicarbonate and provisions of fuel oil, natural gas and activated carbon. The influence of different datasets on the result was found to be relevant in some cases: for instance, the Global Warming impact in Milan was significantly affected by the production of sodium bicarbonate. If $16.8 \mathrm{~kg} \mathrm{Mgww}^{-1}$ of bicarbonate was used (Milan), an associated emission of $85 \mathrm{~kg} \mathrm{CO}_{2}$ was calculated by EASEWASTE while only $5.4 \mathrm{~kg} \mathrm{CO}_{2}$ with SimaPro. Similarly, the provisions of fuel oil, activated carbon and natural gas presented significantly larger Global Warming impacts in EASEWASTE compared with SimaPro, leading to a net load in EASEWASTE while a net saving in SimaPro, indicating that even secondary processes can influence the results and that accurate datasets are needed for all the processes included in the modelling. This was the case for process inventories for provision of activated carbon and sodium bicarbonate, which were responsible for the different results between models (higher potential impacts for SimaPro) for Ecotoxicity in water due to emissions of metals, in particular copper to water, and Human Toxicity via soil (mainly because of Benzene emissions to air) in the Milan case. In the Aarhus scenario, the two LCA models provided more similar results as no sodium bicarbonate was used.

The intrinsic modelling differences between the two models were responsible for the majority of the differences in Human Toxicity via water and Ecotoxicity in water for Milan. The handling of solid residues is an example of this, especially in the case of Milan which showed differences between the two models in these impact categories. The variations were related to different approaches for estimating emissions from landfills: in EASEWASTE the emissions were modelled as input-specific while in SimaPro they were modelled exclusively as process-specific. The latter is less accurate because the waste composition (and thereby residue quality) cannot be taken into account, unless all the emission factors are manually adjusted to adapt a new waste composition. Consequently, two identical landfills receiving totally different waste would in SimaPro provide identical environmental impacts while the impacts in EASEWASTE would reflect the waste input. These differences had most effect when modelling the Milan system because in Aarhus no APC residues were landfilled (they were utilized for backfilling of mines, according to Fruergaard et al. (2010b)).

Finally, it should be noted that EASEWASTE calculates two additional impact categories: Stored Ecotoxicity, for water and soil respectively. These categories account for the impacts that would potentially occur in case of instant release of contaminants (e.g. heavy metals) from the landfilled residues (Hauschild et al. 2008). These impacts accounted for $295 \mathrm{mPE}$ and $38 \mathrm{mPE}$ for Aarhus and $1115 \mathrm{mPE}$ and $60 \mathrm{mPE}$ for Milan, for water and soil respectively ( $1 \mathrm{mPE}=10^{-3} \mathrm{PE}, \mathrm{a}$ Person Equivalent (PE) corresponds to the environmental impact related to one average person). The difference was due to both the different initial waste composition in the two systems, and the lower stack emissions in Milan resulting in larger quantities of contaminants routed to the solid 
residues (in particular adsorbed on activated carbon) and thus "stored" in landfills. EASEWASTE directly estimate potential future emissions, while with SimaPro it is necessary to perform further calculation on the outcomes on the model to estimate those impacts.

\subsection{Significance of waste input composition}

A sensitivity scenario was developed to evaluate the influence of waste composition data on the environmental profile of the two incinerators. In the scenario, the waste input from Milan was now used for Aarhus and vice versa. All other parameters used in the modelling were maintained as before (Table 1). This sensitivity scenario was implemented only in EASEWASTE, because no input specific emissions could be modelled in SimaPro. This modelling exercise provided information about the technological aspects of waste incineration, as a situation where Danish waste was treated in an incinerator with Italian technology (and vice versa) was simulated. The scenario also highlighted the differences between Italy and Denmark as well as the different systems/contexts for the incineration plants.

The results are discussed only with respect to the incineration process because this was the process mostly affected by a change in input waste. The new waste composition influenced "input specific emissions", i.e. $\mathrm{CO}_{2}$ (biogenic and fossil) and heavy metals ( $\mathrm{As}, \mathrm{Cd}, \mathrm{Cr}, \mathrm{Cu}, \mathrm{Hg}, \mathrm{Mn}, \mathrm{Ni}, \mathrm{Pb}, \mathrm{Sn}$, $\mathrm{Zn})$, as well as energy recovery and related avoided emissions.

Figure 5 presents the results of the sensitivity scenario. The results showed that the impact categories mostly affected by the change were: Global Warming and Human Toxicity via water, in which some of the impacts were "reversed" from environmental loads to savings. This indicates that environmental impacts in the above mentioned categories can be significantly influenced by the waste composition and that site-specific modelling of waste specific emissions and energy recovery is important. As none of the input specific emissions affected Acidification, Nutrient Enrichment and Photochemical Ozone Formation, the differences in these categories were attributed only to the different LHVs of the waste. Consequently, the Aarhus scenario with the Italian waste provided greater savings due to the high energy recovery of the Aarhus plant.

Three factors affected the toxicity categories: the content of micropollutants in the input waste, the transfer coefficients and the avoided emissions from energy substitution. Large differences compared to the base scenarios were found for Human Toxicity via water and Human Toxicity via soil, which largely depended on input-specific emissions, in particular mercury for Human Toxicity via water and both mercury and arsenic for Human Toxicity via soil.

The transfer coefficients for the Milan incinerator resulted in higher mercury emissions to air compared with the Aarhus incinerator (more effectively removing mercury from the flue gas). This combined with the fact that the Danish waste was more contaminated by mercury, resulted in the largest impacts in Human Toxicity via water for the Milan scenario with Danish waste, while the opposite was the case when the "original" waste was used for the modelling (i.e. Figure 5). Conversely, the Milan scenario with Danish waste had an inferior performance compared with the original Italian waste. 


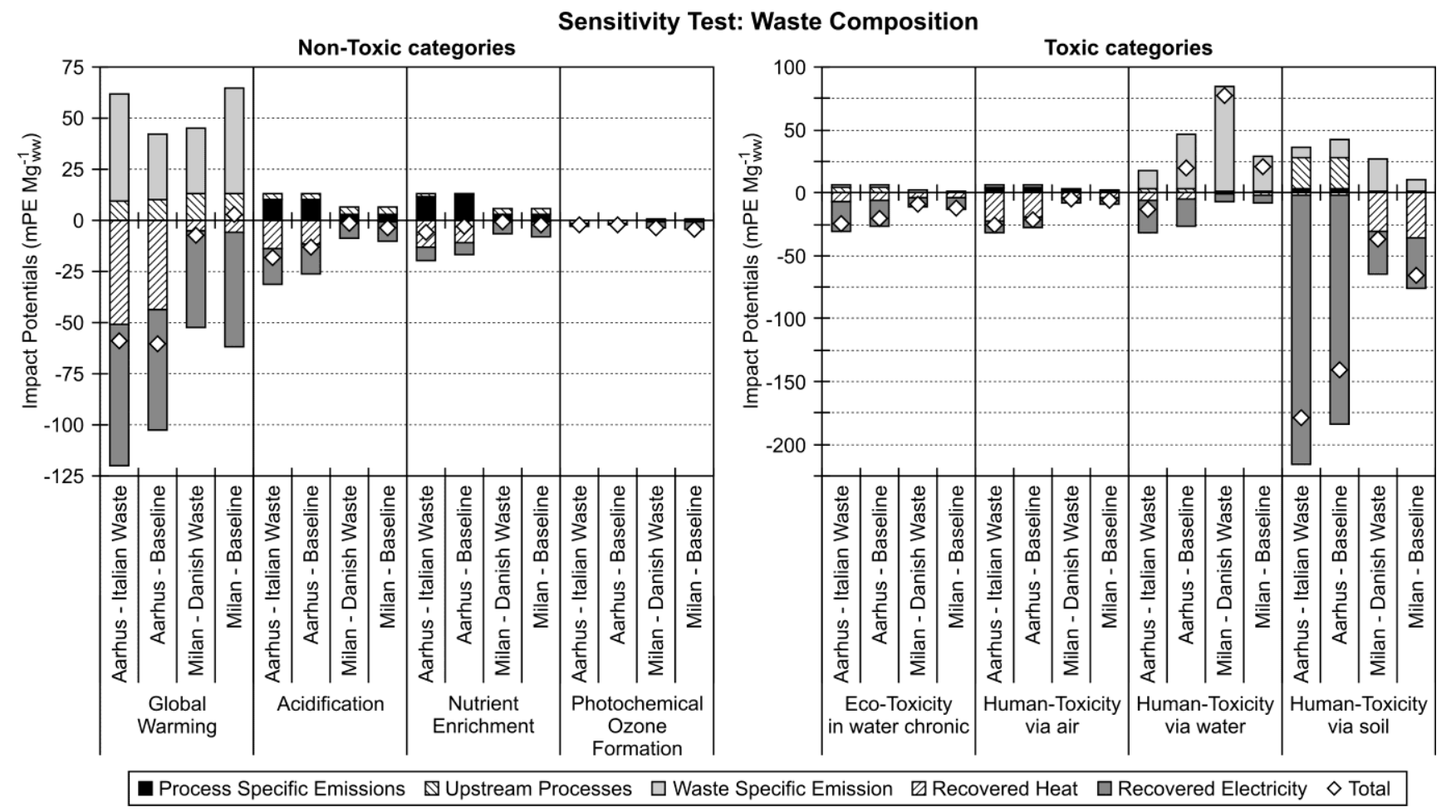

Figure 5. Normalized environmental impact potentials for scenarios with changes in waste input. Results for the baseline scenarios (identical to EW data in Figure 4) are included for comparison.

\subsection{Significance of energy substitution}

Besides technological differences between the incinerators, the local system context can lead to differences in the environmental performances of the two systems. The present study can be considered in a broader perspective as a comparison of the typical situation for northern and southern Europe. As previously pointed out, energy recovery is a key issue that strongly depends on the geographical context (Grosso et al. 2010). The colder climate together with highly developed district heating networks in Northern European countries lead to a greater demand for heat from the waste incinerators. On the other hand, in southern Europe the main focus is on electricity production, due to the presence of smaller district heating networks and lower heat requirements.

An additional scenario for each plant was developed in both models by changing the substituted electricity source. The Italian marginal electricity production was changed from natural gas to coal, while in the Danish scenario substituted electricity was changed from coal to natural gas. Figure 6 presents the results of this sensitivity analysis. 

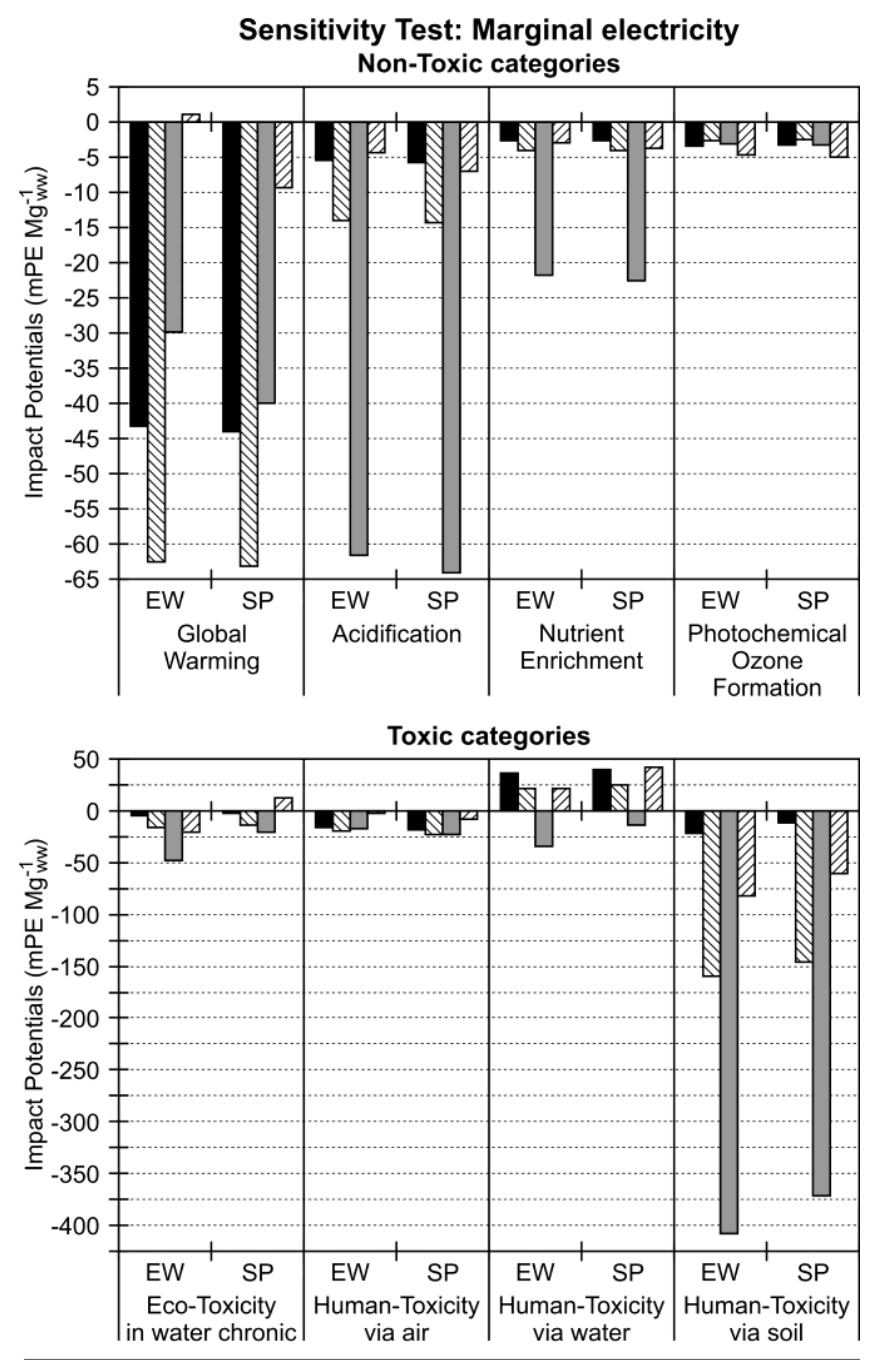

Aarhus - Gas $\otimes$ Aarhus - Baseline $\square$ Milan - Coal $\square$ Milan - Baseline

Figure 6. Normalized environmental impact potentials for scenarios with changes in marginal electricity (SP = SimaPro, EW = EASEWASTE). Results for the baseline scenarios (identical to EW data in Figure 4) are included for comparison.

The Aarhus incinerator still provided the largest savings in term of Global Warming, as the smaller benefits from energy substitution were compensated by a lower share of fossil $\mathrm{CO}_{2}$ in the flue gas (a consequence of the higher content of organics in the waste input). On the other hand, the Milan incinerator provided larger benefits than the Aarhus plant for the toxic categories. It can, thereby, be concluded that with different assumptions regarding marginal electricity, the Milan incinerator could demonstrate a better overall performance than the Aarhus incinerator (with exception of Global Warming). Again this emphasizes that applying appropriate site-specific data when assessing waste incinerator can be critical for the outcome of an LCA comparison.

\section{Conclusions}

Choices regarding energy recovery and selection of marginal electricity, and air emissions from the incinerator were most critical for the modelling results. Upstream processes represented a significant burden in some cases, mainly for Human Toxicity via soil. Non-toxicity impacts were 
generally found to be smaller than the toxicity impacts, with exception of Global Warming. Solid residue management only had small effects on the non-toxicity categories, mainly due to the small quantities in question. The Danish incinerator (Aarhus) overall showed more environmentally friendly than the Italian incinerator (Milan), as the Danish system had lower impacts for all impact categories except Photochemical Ozone Formation. This was partly due to different waste compositions influencing input-specific emissions and recovered energy, and ultimately affecting Global Warming and Human Toxicity via Water. The flue gas cleaning system at the Italian facility was preferable to the Danish; however, the impacts related to handling of solid residues in Milan were higher than in Aarhus, indicating that pre-treatments before final disposal of solid residues may in some cases represent an important environmental burden. The two LCA models employed (SimaPro and EASEWASTE) provided consistent ranking of the scenarios; however important differences in the results were identified for three impact categories: Ecotoxicity in Water and Human Toxicity via Water, and to a lesser extent Global Warming. These differences were mainly related to the fact that SimaPro did not model input-specific emissions), but also differences in model databases affected the results although key process data (e.g. energy substitution, metal recycling) were standardized between the two databases prior to modelling. The modelling clearly showed that accurate databases and appropriate site-specific process data are critical. 


\section{References}

AffaldVarme Aarhus (ed.) (2008) Grønt Regnskab 2008 Forbrændingsanlægget.AffaldVarme Aarhus, Bautavej I, 8210 Aarhus, Denmark (Green account 2008 Incineration plant). Last accessed Juli 2010 at: http://www.aarhuskommune.dk/ /media/Subsites/AffaldVarme-Aarhus/OmAffaldVarme-Aarhus/Bibliotek/Groenne-regnskaber/2009/Forbraending-regnskab-2009.ashx (In Danish).

Amsa (ed.) (2008) Dichiarazione Ambientale Termovalorizzatore Milan 2. Technical report, Amsa S.p.A (Green Account of Milan 2 Incineration plant, in Italian). Last accessed November 2010 at:

http://www.amsa.it/gruppo/export/sites/default/amsa/azienda/governance_sostenibilita/do cumenti/DICHIARAZIONE_AMBIENTALEx1x.pdf

Astrup, T., Møller, J., Fruergaard T. (2009) Incineration and co-combustion of waste: accounting of greenhouse gases and global warming. Waste Management and Research 27, 789-799.

Consonni, S., Giugliano, M., Grosso, M. (2005) Alternative strategies for energy recovery from municipal solid waste. Part A: mass and energy balances. Waste Management 25, 123-135.

Damgaard, A., Riber, C., Fruergaard, T., Hulgaard, T., Christensen, T.H. (2010) Life-cycle-assessment of the historical development of air pollution control and energy recovery in waste incineration. Waste Management 30, 1244-1250.

Dones, R., Bauer, C., Bolliger, R., Burger, B., Faist Emmenegger, M., Frischknecht, R., Heck, T., Jungbluth, N., Röder, A., Tuchschmid, M. (2007) Life cycle inventories of energy systems: results for current systems in Switzerland and other UCTE countries. Ecoinvent report No. 5. Paul Scherrer Institut Villigen, Swiss Centre for Life Cycle Inventories, Dübendorf, Switzerland.

DONG Energy (ed.) (2008) Studstrupværket - Grønt regnskab 2007 (Studstrupværket - Green Account 2007). DONG Energy, Denmark (in Danish). Last accessed November 2010 at: http://www.dongenergy.com/da/forretningsaktiviteter/generation/elproduktion/centrale\%20 kraftvaerker/pages/studstrupvaerket.aspx

Emery, A., Davies, A., Griffiths, A., Williams, K. (2007) Environmental and economic modelling: A case study of municipal solid waste management scenarios in Wales. Resources, Conservation and Recycling 49, 244-263.

Euroheat (ed.) (2007) District heating \& cooling - 2007 statistics. Last accessed November 2010 at: http://www.euroheat.org/Admin/Public/DWSDownload.aspx?File=\%2fFiles\%2fFiler\%2fDHC 2 007 Statistics Table(2).pdf

EC (ed.) (2010) EU energy and transport in figures: Statistical Pocketbook 2010. Part 2: Energy. European Commission Directorate-General for Energy and Transport, Luxemburg. Last accessed November 2010 at: 
http://ec.europa.eu/energy/publications/doc/statistics/part 2 energy pocket book 2010.p $\underline{\mathrm{df}}$

Finnveden, G., Ekvall, T. (1998) Life-cycle assessment as a decision-support tool-the case of recycling versus incineration of paper. Resources, Conservation and Recycling 24, 235-256.

Finnveden, G., Johansson, J., Lind, P., Moberg, Å. (2005) Life cycle assessment of energy from solid waste - part 1: general methodology and results. Journal of Cleaner Production 13, 213-229.

Finnveden, G., Hauschild, M.Z., Ekvall, T., Guinée, J., Heijungs, R., Hellweg, S., Koehler, A., Pennington, D., Suh, S. (2009) Recent developments in life cycle assessments. Journal of Environmental Management 91, 1-21.

Frischknecht, R., Rebitzer, G. (2005) The ecoinvent database system: a comprehensive web-based LCA database. Journal of Cleaner Production 13, 1337-1343.

Fruergaard, T., Ekvall, T., Astrup, T. (2009) Energy use and recovery in waste management and implications for accounting of greenhouse gases and global warming contributions. Waste Management and Research 27, 724-737.

Fruergaard, T., Astrup, T. (2011) Optimal utilization of waste to energy in an LCA perspective. Waste Management 31, 572-582.

Fruergaard, T., Christensen, T.H., Astrup, T. (2010a) Energy recovery from waste incineration: Assessing the importance of district heating networks. Waste Management 30, 1264-1272.

Fruergaard, T., Hyks, J., Astrup, T. (2010b) Life-cycle assessment of selected management options for air pollution control residues from waste incineration. Science of the Total Environment $408,4672-4680$.

Grosso, M., Motta, A., Rigamonti, L. (2010) Efficiency of energy recovery from waste incineration, in the light of the new Waste Framework Directive. Waste Management 30, 1238-1243.

Hauschild, M., Olsen, S., Hansen, E., Schmidt, A. (2008) Gone... but Not Away - Addressing the Problem of Long-Term Impacts from Landfills in LCA. International Journal of LCA 13, 547-554.

IPCC (ed.) (2007) IPCC Fourth Assessment Report -Working Group 1. Technical report, International Panel on Climate Change. Page 212.

IPPC (ed.) (2001) Best Available Techniques Reference Document in the Non Ferrous Metal Industries. Technical report, Integrated Pollution Prevention and Control.

IPPC (ed.) (2009) Best Available Techniques Reference Document for Production of Iron and Steel (Draft). Technical report, Integrated Pollution Prevention and Control. 
Kirkeby, J.T., Hansen, T.L., Birgisdóttir, H., Bhander, G.S., Hauschild, M.Z., Christensen, T.H. (2006) Environmental assessment of solid waste systems and technologies: EASEWASTE. Waste Management \& Research 24, 3-15.

LCA-center (ed.) (2008) EDIP database (Environmental Design of Industrial Products). Last accessed November 2010 at: http://www.lca-center.dk/cms/site.aspx?p=728.

Liamsanguan, C., Gheewala, S.H. (2007) Environmental assessment of energy production from municipal solid waste incineration. International Journal of Life Cycle Assessment, 12, 529536.

Mendes, M.R., Aramaki, T., Hanaki, K. (2004) Comparison of the environmental impact of incineration and landfilling in Sao Paulo City as determined by LCA. Resources, Conservation and Recycling 41, 47-63.

PE International (ed.) (2010) Gabi Software, Gabi 4. PE International. Last accessed July 2010 at: http://www.gabi-software.com/ce-eu-english/software/gabi-4/

Pré Consultants (ed.) (2008) SimaPro 7.1, Pré Consultants, Amersfoort, The Netherlands. Last accessed July 2010 at: http://www.pre.nl/simapro/

Regione Lombardia (ed.) (2004) Bollettino Ufficiale. Secondo supplemento straordinario al n. 22; 27 maggio 2004. Regione Lombardia, Italy (in Italian)

Reimann, D.O. (2009) CEWEP Energy Report II (status 2004-2007). CEWEP, Bamberg, Germany. Last accessed July 2010 at:

http://cewep.com/storage/med/media/statements/258_Hand_out_Energy_Efficiency_Report_Mar ch 2009 final.pdf

Riber, C., Bhander, S. G., Christensen, T.H. (2008) Environmental assessment of waste incineration in a life-cycle-perspective (EASEWASTE). Waste Management and Research 26, 96-103.

Rigamonti, L., Grosso, M., Giugliano, M. (2009) Life cycle assessment for optimising the level of separated collection in integrated MSW management systems. Waste Management 29, 934944.

Schmidt, J. H., Holm, P., Merrild, A., Christensen, P. (2007) Life cycle assessment of the waste hierarchy - A Danish case study on waste paper. Waste Management 27, 1519-1530.

Stranddorf, H.K., Hoffmann, L., Schmidt, A. (2005) Impact categories, normalisation and weighting in LCA, Updated on selected EDIP97-data. Environmental News No. 995 2005. Danish Environmental Protection Agency, Danish Ministry of the Environment, Copenhagen, Denmark. Last accessed September 2010 at: http://www2.mst.dk/udgiv/publications/2005/87-7614-570-0/pdf/87-7614-571-9.pdf 
Wenzel, H., Hauschild, M., Alting, L. (1997) Environmental assessment of products, vol.1: Methodology, tools and case studies. Kluwer Academic Publishers, Hingham, MA.

Winkler, J., Bilitewski, B. (2007) Comparative evaluation of life cycle assessment models for solid waste management. Waste Management 27, 1021-1031. 